\title{
Analisis Strategi Marketing Public Relations PT. Bank Rakyat Indonesia (Persero) tbk dalam Meningkatkan Pengguna Kartu Brizzi
}

\author{
Muhammad Imron Rosyadi ${ }^{1, a)}$ \\ ${ }^{1}$ Detik.com \\ a)adirosyadi2289@gmail.com \\ DOl:https://doi.org/10.18196/jkm.101001
}

Info artikel

Sejarah artikel :

Diterima 20 Mei 2017

Revisi 7 Okt 2017

Disetujui 15 Des 2017

\begin{abstract}
Marketing Public Relations Strategy of PT. Bank Rakyat Indonesia (Persero) Tbk Branch Office of Yogyakarta in improving BRIZZI Card users. The results of this research showed that the public relations marketing program in increasing the number of BRIZZI card users performed special event programs, sponsorship, BRIZZI Trans Jogja, direct presentations, telemarketing, exhibitions event, advertising strategy, bundling, and BRIZZI co-branding or cooperation and also supported with various roles and functions performed by PT. Bank Rakyat Indonesia (Persero) Tbk Branch Office of Yogyakarta. The conclusion can be seen from the increasing number of BRIZZI card users in October which far exceeded the target. The implementation of marketing public relations program would be maximal again if supported by the role of the optimal marketing media, through concerted media (centralize activities on the media) in order that the publication can be realized with the maximum. Using concerted media, PT. Bank Rakyat Indonesia (Persero) Tbk Branch Office of Yogyakarta can attract customers to reach the target and of course will make the increase of BRIZZI card users.
\end{abstract}

Keywords: Marketing; Public Relations; Strategy; e-money; BRIZZI

\begin{abstract}
ABSTRAK
Strategi Marketing Public Relations PT. Bank Rakyat Indonesia (Persero) Tbk Kantor Cabang Yogyakarta dalam meningkatkan pengguna Kartu BRIZZI.Dalam analisis data penelitian ini menggunakan menggunakan jenis analisis data model analisis interaktif. Hasil penelitian dapat diketahui bahwa program marketing public relations dalam meningkatkan jumlah pengguna kartu BRIZZI melakukan program special event, sponsorship, BRIZZI Trans Jogja, directpresentations, telemarketing, exhibitions event, strategi periklanan, bundling, serta BRIZZI co-branding atau melakukan kerjasama dan juga didukung dengan berbagai peran dan fungsi yang dilakukan PT. Bank Rakyat Indonesia (Persero) Tbk Kantor Cabang Yogyakarta.Kesimpulannya dapat dilihat dari peningkatan jumlah pengguna kartu BRIZZI pada bulan Oktober yang jauh melebihi target. Dalam pelaksanaan program marketing public relationsakan lebih maksimal lagi jika didukung dengan peran dari media pemasaran yang optimal, dapat melalui media yang concerted (memusatkan kegiatan pada media) agar publikasi dapat terwujud dengan maksimal. Menggunakan media yang concerted PT. Bank Rakyat Indonesia (Persero) Tbk Kantor Cabang Yogyakarta dapat manarik nasabah sehingga mencapai target dan tentu saja akan membuat peningkatan pengguna kartu BRIZZI
\end{abstract}

Kata kunci :Marketing, Public Relations, Strategy, e-money. BRIZZI

\section{PENDAHULUAN}

Tingkat pertumbuhan ekonomi suatu negara dapat ditandai dengan munculnya berbagai macam sektor industri vital. Sektor ini memberikan keuntungan, baik itu industri pelayanan jasa transportasi, jasa kesehatan, dan jasa penyedia makanan dan minuman. Hal yang merupakan faktor penentu dari 
keberhasilan pertumbuhan ekonomi suatu negara adalah industri yang bergerak dalam bidang pelayanan jasa perbankan.

Dunia perbankan saat ini semakin berkembang, dimana masyarakat tidak hanya memandang sebuah bank sebagai sarana untuk menyimpan uang.Lebih dari itu, investasi dunia perbankan saat ini jauh lebih tinggi, sehingga menciptakan suasana persaingan antar bank dalam penggalangan dana nasabah yang semakin ketat. Berbagai kegiatan dan program dilakukan untuk dapat menarik perhatian dan kesadaran dari masyarakat. Selain itu, program-program dan kegiatan tersebut juga bertujuan untuk memperhatikan posisi perusahaan dihati masyarakat dan stakeholder lain.

Salah satu lembaga negara di bidang perbankan, adalah PT. Bank Rakyat Indonesia (Persero).Perusahaan ini merupakan jasa perbankan di Indonesia yang tetap berusaha untuk meningkatkan jumlah nasabah, dan tidak boleh menimbulkan dampak negatif bagi semua pihak. Segala kegiatan dan program yang melibatkan masyarakat luas harus bersifat terbuka.

PT Bank Rakyat Indonesia (Persero) selalu berusaha untuk menarik minat dengan berbagai kelebihan. Hal inilah yang menjadi nilai lebih sehingga harus direalisasikan melalui pelaksanaan program marketingpublic relations yang merupakan proses perencanaan, pelaksanaan, dan pengevaluasian program. programmarketingpublic relationsdigunakan untuk kepuasan konsumen melalui komunikasi yang menghubungkan perusahaan dan produknya sesuai dengan kebutuhan, keinginan, perhatian, dan kepentingan konsumen.

Tanpa adanya suatu program yang terencana, program marketingpublic relations terpaksa beroperasi secara instinktif sehingga mudah kehilangan arah, dan selalu tergoda mengerjakan hal-hal baru, sementara hal-hal yang lama belum terselesaikan, yang pada akhirnya sulit memastikan sejauh mana kemajuan yang telah dicapai, dan apa saja hasil-hasil konkret yang telah dihasilkan (Jefkins, 1992:50).

Salah satu program marketingpublic relations juga dapat melakukan interaksi yang baik dengan para konsumennya melalui cara-cara komunikasi.Segala kegiatan interaksi dan timbulnya sikap saling ketergantungan diantara anggota organisasi (baik intern maupun ekstern) dapat terjadi karena adanya pengaruh komunikasi.Melalui komunikasi inilah pengaruh atas perilaku yang timbul dari setiap individu dapat terjadi, menurut Cutlip dan Center (dalam Krisyantono, 2008:19).

Proses program marketingpublic relations memerlukan tindakan untuk mempengaruhi pengetahuan, pendapat dan tindakan khalayak sasaran (Morrissan, 2008:204), dilihat dari efektifitas yang timbul dari proses suatu sistem komunikasi itu sangat tergantung pada kemampuan untuk merespon segala sesuatu yang baik, berupa perubahan yang terjadi di lingkungan luar maupun di dalam organisasi, sesuai dengan tingkat perkembangan internal organisasi itu sendiri. Persuasif berjalan bersamaan dan saling mendukung, dalam arti komunikasi yang dilakukan untuk proses komunikasi dapat menimbulkan pemahaman pada penerima, agar bersikap maupun berpendapat sesuai dengan keinginan organisasi dan program marketing public relations yang telah tercipta, sehingga dapat mendukung organisasi. Melalui program ini, sehingga dapat tercapainya komunikasi yang bersifat dinamis dengan efektifitas yang tinggi.

Program marketing public relationsakan menjadi efektif seiring dengan tercapainya komunikasi yang dinamis. Bentuk dalam menyampaikan suatu pesan dapat berupa lambang, bahasa lisan maupun tulisan dengan mempergunakan satu atau berbagai macam media sebagai saluran penyampaian pesan.

Bentuk penyampaiannya sendiri dapat berupa media yang bersifat massal, seperti media televisi, media cetak, dan pemanfaatan event berskala nasional maupun internasional.Melalui sarana komunikasi tersebut informasi atau pesan dapat tersampaikan ke target audience secara efektif dan dapat pula mempengaruhi pendapat atau sikap dan tindakan audience yang menerima pesan atau informasi tersebut.

Hal terpenting dari program public relations adalah dapat menguasai segala suatu masalah yang dapat timbul antara pesan, saluran ataupun media yang digunakan dalam menyampaikan pesan tersebut kepada khalayak. Tujuannya untuk mengetahui tentang karakteristik atau sifat dan fungsi yang dimiliki dari aspek-aspek suatu proses komunikasi agar dapat tercapai target sehingga dapat dicapai secara maksimal.

Salah satu program yang oleh terencana PT Bank Rakyat Indonesia (Persero), adalah program marketing public relations PT Bank Rakyat Indonesia (Persero) dalam meningkatkan jumlah nasabah.Melalui program yang efektif, PT Bank Rakyat Indonesia (Persero) melakukan berbagai macam penawaran agar dapat menarik minat masyarakat untuk menggunakan jasa dan produk yang ditawarkan.Program yang ditawarkan secara langsung merupakan salah satu penyampaian pesan dan 
informasi tentang BRIZZI yang dilaksanakan secara tepat dan terfokus, sehingga nasabah merasa tertarik dan menggunakan kartu BRIZZI.

BRIZZI adalah uang elektonik BRI, BRIZZI merupakan sarana pembayaran melalui marchantmarchant yang telah bekerja sama dengan BRI. Transaksi yang dilakukan menggunakan chip dengan saldo maksimal Rp.1.000.000,-. Penggunaan kartu BRIZZI sendiri dapat dimiliki oleh siapapun tanpa harus memiliki rekening BRI. Selain itu, keuntungan yang diperoleh yaitu nilai uang di dalam kartu dapat diisi ulang/Top Up (via EDC maupun ATM), Isi ulang BRIZZI dapat melalui rekening BRI maupun Bank lain, dan pembayaran transaksi mulai dari Rp.1,- sampai dengan Rp.1.000.000,Transaksi dapat dilakukan dengan cepat dan mudah, tidak melakukan pembayaran dengan menggunakan uang tunai dan tidak direpotkan dengan uang recehan(http://www.bri.co.id/articles/89)

PT Bank Rakyat Indonesia (Persero) dengan kartu BRIZZI, selalu berusaha menarik minat dengan berbagai kelebihan yang harus direalisasikan. Melalui pelaksanaan Program Public Relationsdengan menggunakan proses perencanaan, pelaksanaan, dan pengevaluasian program agar dapat merangsang kepuasan konsumen melalui kesan-kesan yang menghubungkan perusahaan dan produknya sesuai dengan kebutuhan, keinginan, perhatiaan, dan kepentingan para konsumen.

Marketing Public Relations mempunyai tujuan yang paling penting yaitu merangsang pembelian dan kepuasan dari para konsumen serta komunikasi yang dapat dipercaya, marketing public relations tidak lepas dari kata 'promosi' yaitu merupakan bagian dari proses pemasaran yang berhubungan dengan produk, tempat, harga, dan promosi (produk, place, price and promotion) (Ruslan, 2002:251), yang menjadi bagian dari kampanye pemasaran yang berhasil, namun marketing public relations akan berperan dengan baik dalam menciptakan kampanye pemasaran yang berhasil bila unsur-unsur pemasaran lain juga menyatu dengan public relations.

Di sini Marketing Public Relations sangat dibutuhkan oleh perbankan yang tidak hanya menjual suatu produk atau jasa saja, tapi bagaimana bisa mengkomunikasikan dengan baik agar produk atau jasa bisa terjual. Persaingan marketing sekarang sudah mulai merajalela, marketing public relations sebisa mungkin harus mempunyai proses-proses tertentu untuk meningkatkan kualitas penjualan suatu perusahaan. Dalam hal ini, untuk melakukan peningkatan nasabah pengguna kartu BRIZZI, Marketing Public Relations PT Bank Rakyat Indonesia (Persero) harus memperkenalkan kartu BRIZZI kepada khalayak.Melalui Marketing Public Relations inilah kegiatan promosi dan pemasaran dilakukan agar tercapainya peningkatan jumlah nasabah dalam menggunakan kartu BRIZZI dengan tetap mengutamakan kepuasan dan pelayanan bagi para nasabah.

Meningkatnya jumlah nasabah mempunyai peran yang besar dalam meningkatan profit bagi PT Bank Rakyat Indonesia (Persero).Sehingga bagianmarketing public relations PT Bank Rakyat Indonesia (Persero) harus menitik beratkan pada intensitas kegiatan pemasaran pada faktor penjualan produk dan minat nasabah yang berpengaruh pada peningkatan jumlah nasabah.

Analisis program Marketing Public Relations dalam meningkatkan jumlah nasabah melalui program Marketing Public Relationsbertujuan agar dapat mencapai sasaran yang disajikan dalam bentuk peningkatan awareness sehingga dapat memberikan kepercayaan bagi para nasabah. Berdasarkan strategi Marketing Public Relationssendiri terdiri dari beberapa aktivitas yang bertujuan untuk menarik minat nasabah dengan memberikan motivasi agar tertarik dalam menggunakan kartu BRIZZI serta menikmati layanan dan kualitas yang ditawarkan oleh PT Bank Rakyat Indonesia (Persero).

Oleh karena itu penelitian ini lebih ditekankan pada program Strategi Marketing Public RelationsPT. Bank Rakyat Indonesia (Persero) Tbk Kantor Cabang Yogyakarta dalam meningkatkan penggunaan kartu BRIZZI.

Berdasarkan latar belakang di atas, maka permasalahan dalam penelitian ini dirumuskan sebagai berikut "Bagaimana Strategi Marketing Public RelationsPT. Bank Rakyat Indonesia (Persero) TbkKantor Cabang Yogyakarta dalam meningkatkan penggunaan kartu BRIZZI?

Dengan tujuan untuk mengetahui strategi marketing public relationsPT. Bank Rakyat Indonesia (Persero) Tbk Kantor Cabang Yogyakarta dalam meningkatkan penjualan kartu BRIZZI.Untuk mengidentifikasi faktor-faktor pendukung, penghambat dan pelaksanaan penyusunan strategi marketing public relations PT. Bank Rakyat Indonesia (Persero) Tbk Kantor Cabang Yogyakarta dalam meningkatkan penggunaan kartu BRIZZI.

Marketing Public Relations (MPR)

Aktifitas public relations dalam mendukung marketing dan sasaran penjualan sehingga dikenal dengan istilahmarketing public relations. Staf public relations yang bekerja dibidang ini biasanya 
tergabung dalam divisi marketing public relations yang berorientasi marketing, dibentuk dalam divisi baru yakni "komunikasi dan marketing". Public Relations dapat memperluas peranannya dalam bidang pemasaran produk atau jasa. Terintegrasinya aktifitas public relations dalam marketing, dikarenakan peningkatan kebutuhan dan minat konsumen, harga yang semakin kompetitif, sehingga perlu memperluas distribusi, dan banyaknya promosi dari produk atau jasa dari perusahaan lain.

Marketing public relations dalam perusahaan mulai mendapat perhatian, dikarenakan pentingnya kegiatan komunikasi dalam menunjang kegiatan pemasaran, sehingga pemasaran menjadi lebih efektif dan efisien.Bahkan hubungan dengan konsumen menjadi lebih dekat dan diharapkan menciptakan image yang baik bagi perusahaan.

Marketing public relations adalah konsep public relations yang berorientasi pemasaran artinya sebelum dan sesudah marketing dijalankan public relations melakukan kegiatan image building (pembentukan citra) suatu produk atau jasa yang positif, bila citra perusahaan, produk atau jasa sudah positif di mata konsumen maka mempermudah upaya pemasaran public yaitu untuk mengubah public menjadi konsumen lalu menjadi pelanggan.

Sementara itu Thomas L. Harris, pencetus pertama konsep marketing public relations menulis dalam bukunnya The marketer's guide to public relations sebagai berikut "Marketing public relations merupakan proses perencanaan, pelaksanaan dan pengevaluasian program-program yang merangsang pembelian dan kepuasan konsumen melalui komunikasi mengenai informasi yang dapat dipercaya dan melalui kesan-kesan yang menghubungkan perusahaan dan produknnya sesuai dengan kebutuhan, keinginan, perhatian dan kepentingan para konsumen” (dalam Valasco, 1994:30).

Philip Kotler menyimpulkan bahwa secara garis besar dalam marketing public relationsterdapat tiga taktik (thee ways strategy) untuk melaksanakan program dalam mencapai tujuan (goals) melaksanakan program public relations merupakan petensi untuk menyandang suatu taktik pull strategy (menarik), sedangkan kedua adalah power (kekuatan) sebagai penyandang, push strategy (untuk mendorong) dalam hal pemasaran, taktik ketiga pass strategy sebagai upaya mempengaruhi atau menciptakan opini public yang menguntungkan (Ruslan, 2002:254).

\section{Teori Pemrosesan dan Penerimaan Pesan}

Adapun Teori yang dihubungkan dengan penelitian ini adalah Teori Pemrosesan dan Penerimaan Pesan yang dikemukakan oleh Littlejohn (1996:129) bahwa teori ini menitik beratkan pada bagaimana manusia memahami dan mengorganisasikan, serta menggunakan informasi yang terkandung di dalam pesan. Teori ini dapat dikaitkan dengan bagaimana marketing public relations menghadapi persaingan dalam segi kualitas produk, harga, serta pelayanan terhadap konsumen yaitu dalam hal ini adalah PT. Bank Rakyat Indonesia (Persero) bersaing dengan perusahaan yang menawarkan jasa perbankan lainnya.

Untuk mendapatkan kejelasan tentang teori pemrosesan dan penerimaan pesan menurut Littlejohn, penulis menjabarkan teori tersebut sebagai berikut:

1. Trait ekplanation

Memfokuskan pada karakteristik individu, dan cara-cara karakteristik ini dikaitkan dengan ciri atau sifat-sifat dan variabel yang lainnya terutama berkaitan dengan hubungan antara tipe personalitas tertentu dengan jenis-jenis pesan tertentu.

2. State explanation

Memfokuskan pada kondisi pikiran (states of mind) tidak seperti trait explanation relatif tidak stabil dan dalam kondisi transitory.Aspek ini menjelaskan bagaimana kondisi pikiran tertentu seseorang mempengaruhi pengiriman dan penerimaan pesan.

3. Proses explanation

Mencoba menangkap mekanisme kognitif, yakni menjelaskan proses mekanisme bagaimana informasi diterima dan diorganisasi dalam sistem kognitif individu, bagaimana individu menggunakan sistem memori yang dipergunakan untuk bertindak. Sejumlah teori mengenai hal ini mencakup orientasi kognitif.

Teori-teori kognitif ini mengkonsentrasikan pada proses mental yang menghubungkan antara input dan output, antara stimulus dan respon. Teori-teori kognitif mengasumsikan bahwa kita mempunyai tujuan dan pilihan yang membuat tindakan kita mungkin terwujud. Teori-teori kognitif memfokuskan pada isi, struktur dan proses dalam sistem kognitif individu. Isi dari sistem kognitif (content of cognitive system) terdiri dari informasi, pikiran, sikap dan konsep-konsep. Struktur dari sistem kognitif (structure of cognitive system) terdiri dari bagaimana kita mengorganisasikan isi sistem kognitif tersebut di dalam sebuah perusahaan memori yang kita miliki, sedangkan proses dari sistem 
kognitif ini adalah bagaimana kita mengatur isi yang secara aktual mengubah dan menggunakannya pada dasar kehidupan sehari-hari.

\section{Strategi marketing public relations dalam proses kegiatan sosialisasi}

Marketing public relations merupakan proses perencanaan, pelaksanaan dan pengevaluasian program-program yang merangsang pembeli dan kepuasan konsumen melalui komunikasi serta informasi yang dapat dipercaya, kemudian melalui kesan-kesan yang menghubungkan perusahaan dan produknya sesuai dengan kebutuhan, keinginan, perhatian dan kepentingan para konsumen, konsep Thomas L. Harris. (dalamVelasco, 1994:30). Seiring dengan pemasaran produk atau jasa yang semakin meningkat dan juga sudah memasuki era globalisasi, tidak menutup kemungkinan bahwa tingkat persaingan yang akan timbul lebih tajam dan meningkat dengan cepat. Masing-masing perusahaan berlomba memasarkan produk dan jasa perusahaan tersebut kepada publik agar menjadi tertarik, oleh karena itu untuk menarik minat publik maka peran marketing public relations tidak akan lepas begitu saja.

Adapun tujuan pemasaran yang berhubungan dengan public relations menurut Belc dan Belch 1999 (dalam Gaffar,2007:50) adalah meningkatkan kesadaran, menginformasikan dan memberikan pengetahuan, meningkatkan pemahaman, membangun rasa percaya, memberikan alasan untuk membeli kepada konsumen, serta memotivasi penerimaan konsumen.

Sedangkan Kotler, Bowen dan Makens 2003 (dalam Gaffar,2007:50) mengatakan bahwa marketing public relations dapat berkontribusi terhadap berbagai tujuan pemasaran yaitu meningkatkan kesadaran, membangun kredibilitas, menstimulasi tenaga penjual dan saluran perantara, serta mengurangi biaya promosi.

Marketing Public Relations memberikan nilai tambah terhadap program komunikasi pemasaran terpadu dalam beberapa cara yaitu, membangun daya tarik pasar sebelum muncul periklanan di media, sebagai contoh pemberitaan mengenai produk baru yang merupakan suatu peluang bagi para pemasar untuk mendapatkan publisitas dan mendramatisasikan produk, sehingga akan meningkatkan efektifitas dari iklan untuk mendorong program komunikasi di mana tidak ada periklanan, membuat berita periklanan di mana tidak ada berita mengenai produk tersebut sehingga periklanan itu sendiri bisa menjadi fokus dari publisitas, membawa periklanan kedalam kehidupan kita, memperpanjang program promosi, membangun hubungan personal dengan konsumen, mengkomunikasikan manfaat produk baru, mendemonstrasikan tanggung jawab sosial perusahaan dan membangun kepercayaan konsumen, serta mempertahankan produk (Gaffar, 2007:50).

\section{METODEPENELITIAN}

Jenis penelitian yang digunakan adalah Deskriptif Kualitatif, menurut Bogdan dan Taylor (dalam Moleong, 2007: 29) menyebutkan metodologi kualitatif sebagai prosedur penelitian yang menghasilkan data deskriptif berupa kata-kata tertulis atau lisan dari orang-orang dan perilaku yang diamati.Pakar lain, Denzin dan Lincoln (dalam Moleong, 2007: 32) mengatakan bahwa penelitian kualitatif adalah penelitian yang menggunakan latar alamiah, dengan maksud menafsirkan fenomena yang terjadi dan dilakukan dengan jalan melibatkan barbagai metode yang ada.Penelitian kualitatif metode yang biasanya dimanfaatkan adalah wawancara, pengamatan, dan pemanfaatan dokumen. Moleong sendiri mengatakan bahwa penelitian kualitif adalah penelitian yang menghasilkan prosedur analisis yang tidak menggunakan prosedur analisis statistik atau cara kuantifikasi lainnya, hal ini menunjukan ukuran subyektivitas penelitian kualitatif ditentukan oleh tingkat subyektivitas peneliti. Peneliti merupakan bagian dari instrument penelitian, berbeda dengan paradigma kuantitatif dimana peneliti terpisah dari obyek yang ditelitinya.

Dipilihnya jenis metode penelitian ini dikarenakan penelitian ini bertujuan untuk menganalisa gambaran tentang bagaimana strategi marketing public relations yang dilakukan oleh PT. Bank Rakyat Indonesia (Persero) TbkKantor Cabang Yogyakartadalam meningkatkan penggunaan kartu BRIZZI.

\section{Obyek Penelitian}

Dalam penelitian ini yang menjadi obyek penelitian adalah PT. Bank Rakyat Indonesia (Persero) TbkKantor Cabang Yogyakarta.Penulis ingin mengetahui strategi marketing public relations dalam meningkatkan pengguna kartu BRIZZI. 


\section{PEMBAHASAN}

Perencanaan program marketing public relations yang dilakukan oleh Bagian FO (Funding Officer) adalah meningkatkan jumlah nasabah dalam pengguna kartu BRIZZI.Salah satu perencanaannya adalah dengan mengorganisasi dalam berbagai program yang tepat, sehingga dapat sesuai dengan target perusahaan. Untuk kelancaran operasional dalam meningkatkan jumlah nasabah, dalam menggunakan kartu BRIZZI PT Bank Rakyat Indonesia (Persero) Kantor Cabang Yogyakarta perlu menyusun perencanaan yang matang menyesuaikan kebutuhan tingkat produktifitas kinerja. Program yang akan dilaksanakan agar dapat berjalan sesuai dengan program marketing public relations atau Funding Officer.Mengantisipasi terjadinya tumpang tindihnya pekerjaan, keseimbangan beban tugas (work load), kejelasan masing-masing bagian harus sesuai dengan job Describtions (rincian tugas) dalam menarik nasabah PT Bank Rakyat Indonesia (Persero) Kantor cabang Yogyakarta.

Dalam menjalankan strategimarketing public relation perlu diketahui terlebih dahulu siapa yang menjadi target sasaran pengguna kartu BRIZZI. "Target market atau sasaran kartu BRIZZI adalah pelajar, mahasiswa dan masyarakat sebagai segmen pasarnya, sehingga strategi yang digunakan harus sesuai dengan tujuan yang ingin dicapai.

Untuk mencapai tujuan yang diharapkan perusahaan yaitu terciptanya tim kerja yang baik sehingga pelaksanaan program yang dilakukan oleh marketing public relations PT Bank Rakyat Indonesia (Persero) kantor cabang Yogyakarta dapat menarik nasabah agar tertarik menggunakan kartu BRIZZI sebagai kartu e-money.

Tujuan dalam pelaksanaan program adalah sebagai salah satu cara untuk memberikan penjelasaan jika e-money merupakan kartu yang dapat dipercaya oleh masyarakat dan nasabah. Koordinasi sangat diperlukan sehingga dapat berkesinambungan dari atas sampai bawah.Dalam hal ini PT Bank Rakyat Indonesia (Persero) Kantor Cabang Yogyakarta harus memberikan pemahaman dan edukasi dalam menarik nasabah agar mau bergabung dan menjadi nasabah yang menggunakan kartu BRIZZI. Dalam perencanaan tersebut marketing public relations PT Bank Rakyat Indonesia (Persero) Kantor Cabang Yogyakarta harus mengadakan rapat koordinasi dengan Funding Officer agar program yang akan dijalankan dapat berjalan dengan lancar. Rapat diadakan setiap satu bulan sebelumnya dengan tujuan untuk mengevaluasi program yang sudah dilakukan apakah berhasil atau belum. Apabila program yang dilakukan belum menampakkan hasil, maka akan disusun program lainnya, tetapi jika mendapatkan hasil yang dicapai maka program akan dilaksanakan untuk bulan berikutnya.

Marketing public relations atau Funding Officer PT Bank Rakyat Indonesia (Persero) Kantor Cabang Yogyakarta dalam meningkatkan jumlah nasabah pengguna kartu BRIZZI perlu merencanakan berbagai program antara lain.

Special EventsYaitu Menyelenggarakan acara atau kegiatan khusus (Special Event)yangdilakukan oleh marteting Public Relations PT Bank Rakyat Indonesia (Persero) Kantor cabang Yogyakarta. Program ini merupakan salah satu cara untuk menarik perhatian media pers dan publik terhadap produk kartu BRIZZI.

Bundling yaitu setiap nasabah yang membuka rekening di Bank BRI akan langsung mendapatkan kartu BRIZZI kemudian langsung di Top Up senilai lima puluh ribu rupiah.

BRIZZI co-branding yaitu Kerjasama yang dilakukan terkait dengan penggunaan BRIZZI.Cobranding dapat dipakai sebagai akses masuk gate Taman Candi Prambanan, dimana penggunaan $e$ money BRIZZI dapat mengurangi terjadinya antrian panjang di loket Taman Wisata Candi. BRIZZI tidak hanya berperan sebagai tiket masuk tetapi dapat digunakan sebagai alat pembayaran wahana lain di lingkungan Taman Candi.

BRIZZI Trans Jogja yaitu program dalam rangka maningkatkan pengguna kartu BRIZZI. Menggunakan kartu BRIZZI, pembayaran Trans Jogja semakin murah dan hemat "Bayar Trans Jogja pakai BRIZZI cuma Rp 1000“. BRIZZI merupakan kartu prabayar multifungsi, hal ini terlihat karena solusi kecepatan bertransaksi yang sudah diterima di lebih dari 25.000 outlet merchant.

Direct presentations (presentasi langsung) yaitu seorang Marketing Public relations atau Funding Officer datang ke suatu perusahaan mengajukan panawaran untuk presentasi agar perusahaan tersebut tertarik dan mau menjadi pengguna kartu BRIZZI.

Exhibitions event (Pameran) yaitu mengadakan pameran-pameran di mall atau di perusahaanperusahaan yang sudah bekerjasama dangan PT Bank Rakyat Indonesia (Persero).

Strategiiklanadalah Iklan kartu BRIZZI yang menggunakan media cetak.Jenis iklan yang digunakan adalah lini bawah atau below the line. Iklan merupakan media komunikasi kepada 
masyarakat, dimana surat kabar harian dapat menjangkau ke semua lini masyarakat. Di dalam iklan, terdapat logo dan sesuatu yang mendeskripsikan tentang kartu BRIZZI.

Sponsorship merupakan pendanaan yang dilakukan perusahaan untuk melakukan kerja sama atau publisitas sebuah brand.Strategi inimerupakan salah satu carayang digencarkan oleh funding officer setelah special event dan program lainya.Biasanya sponsorship dijalankan untuk event-event yang diadakan pelajar, mahasiswa dan masyarakat.

Sesuai yang telah diungkapkan sebelumnya, bahwa tujuan penelitian ini adalah untuk menganalisis program marketing public relations yang dilakukan oleh PT Bank Rakyat Indonesia (Persero) Kantor Cabang Yogyakarta dalam meningkatkan jumlah pengguna kartu BRIZZI.Berdasarkan penelitian, marketing public relations sangat penting dalam mempromosikan produk suatu perusahaan.Sebuah perusahaan khususnya yang bergerak di bidang jasa perbankan memerlukan marketing public relations untuk memprosmosikan produk agar produk yang dikeluarkan oleh perusahaan dikenal oleh khalayak. Harapan PT Bank Rakyat Indonesia (Persero) Kantor Cabang Yogyakarta, dalam jumlah nasabah pengguna kartu BRIZZI dapat tercapai. Hal inilah yang membuat nasabah tertarik untuk menggunakannya, dengan banyaknya masyarakat yang mengetahui.

Dari hasil penelitian, terlihat program marketing public relations dalam meningkatkan jumlah nasabah yang menggunakan kartu BRIZZI memiliki tahapan-tahapan yang direncanakan.Pelaksanakan direncanakan dengan matang sesuai dengan program marketing public relations PT Bank Rakyat Indonesia (Persero) Kantor Cabang Yogyakarta yang telah ditetapkan.

Untuk mencapai tujuan yang diharapkan, terciptanya Tim kerja yang baik sehingga pelaksanaan program marketing public relationsdalam mempromosikan kartu BRIZZI berjalan dengan lancar.Hal ini, diperlukan koordinasi yang berkesinambungan dari atas sampai bawah.Proses operasionalnya berkoordinasi dari semua bagian yang mempunyai tugas masing-masing sesuai dengan job descriptions.Pembagian pekerjaan pada masing-masing bagian agar tidak terjadi tumpang tindih pekerjaan. Hal ini akan terlihat keseimbangan beban tugas.Kejelasan tugas wawenang dan tanggung jawab masing-masing bagian sehingga dapat bekerja dengan baik dalam melaksanakan berbagai program marketing public relations PT Bank Rakyat Indonesia (Persero) Kantor Cabang Yogyakarta.Tahap selanjutnya yang dilakukan setelah tahap perencanaan adalah pelaksanaan.Tahap pelaksanaan ini funding officer melaksanakan progam-program diantarannyaSpecial Event,Sponsorship, BRIZZI Trans Jogja Direct presentations (presentasi langsung), Telemarketing, Exhibitions event (Pameran), Strategi Periklanan, Bundling, dan BRIZZI Co-branding.

Keberhasilan dalam memperkenalkan dan memberikan pemahaman produk BRIZZI kepada nasabah dengan berbagai kegiatan program marketing public relations telah berjalan sesuai dengan yang diharapkan.Kebanyakan nasabah mengetahui tentang kartu BRIZZI dari berbagai publikasi yang dilakukan oleh PT Bank Rakyat Indonesia (Persero) Kantor Cabang Yogyakarta.Ketertarikan nasabah terhadap kartu BRIZZI didasarkan pada kelebihan yang dimilki oleh kartu BRIZZI yaitu Penggunaan kartu BRIZZI sendiri dapat dimiliki oleh siapapun tanpa harus memiliki rekening BRI. Selain itu, keuntungan yang diperoleh yaitu nilai uang di dalam kartu dapat diisi ulang/Top Up (via EDC maupun ATM), Isi ulang BRIZZI dapat melalui rekening BRI maupun Bank lain, dan pembayaran transaksi mulai dari Rp.1,- sampai dengan Rp.1.000.000,-.Transaksi dapat dilakukan dengan cepat dan mudah, tidak melakukan pembayaran dengan menggunakan uang tunai dan tidak direpotkan dengan uang recehan, sehingga program promosi yang telah dilakukan oleh bagian marketing public relations atau funding officer yang berkerjasama dengan bagian lain telah membuahkan hasil yang memuaskan.Hasil yang dicapai yaitu keberhasilan dalam mempromosikan dan memberikan pemahaman serta meningkatkan jumlah nasabah pengguna kartu BRIZZI.

Berdasarkan uraian diatas secara umum program marketing public relations yang dilakukan oleh funding Officerdalam meningkatkan jumlah nasabah sudah sesuai dengan teori proses dan penerimaan pesan. Teori proses pemprosesan dan penerimaan pesan adalah teori yang berorientasi kognitif. Teori ini membicarakan persoalan yang menyangkut hubungan antar stimulus dan respon.Kognitif sendiri mangacu pada pikiran atau benak seseorang, sehingga Kognitivisme memfokuskan bagaimana individu berfikir apabila ada stimulus dan respon.Teori pemrosesan pesan dan penerimaan pesan adalah teori yang menitik beratkan bagaimana manusia memahami dan mengorganisasikan serta menggunakan informasi yang mengandung di dalam pesan.Teori ini dapat dikaitkan dengan bagaimana marketing public relations dapat mempromosikan suatu produk. 
Kaitan penelitian ini dengan Teori Pemrosesan dan Penerimaan Pesan dalam kegiatan marketing public relations atau funding officer sebagai bagian aktifitas promosi dalam proses penyampaian pesan dari perusahaan yang diwakili. Perusahaan yang bersangkutan disini adalah PT Bank Rakyat Indonesia (Persero) Kantor Cabang Yogyakarta dalam meningkatkan jumlah pengguna kartu BRIZZI.hal ini bertujuan agar pesan yang disampaikan dapat diterima dengan baik oleh para nasabah maupun calon nasabah,sehingga diwujudkan dengan mengadakan berbagai kegiatan program marketing public relations dalam pembuatan kampanye promosi kartu BRIZZI dengan program special event, sponsorship, BRIZZI Trans Jogja, directpresentations, telemarketing, exhibitions event, strategi periklanan, bundling, serta BRIZZI co-branding. Tanpa menghilangkan tujuan utama yaitu memberikan pemahaman serta menawarkan kartu BRIZZI dengan keunggulan dan kualitas dari produk yang dikeluarkan oleh bank BRI. Kegiatan program marketing public relations dapat berjalan dengan baik.Keinginan untuk mempengaruhi nasabah dalam berfikir dan melakukan tindakan untuk tertarik menggunakan produk kartu BRIZZI ini bisa disimpulkan dengan kaitannya teori yang digunakan telah sesuai dengan penelitian.

Program marketing public relations yang paling obyektif adalah melalui Bundling. Penawaran ini dapat membuat nasabah merasa lebih percaya dan lebih yakin akan produk kartu BRIZZI yang ditawarkan oleh marketing public relations atau funding officer.Penawaran dilakukan secara langsung dengan pelayanan yang menarik melalui komunikasi dua arah dan dapat berdiskusi bersama.Masyarakat belum menyadari mudahnya sebuah penggunaan kartu BRIZZI, hal ini yang menyebabkan nasabah kurang tertarik menggunakan kartu BRIZZI.Namun, melalui penawaran lewat Bundling nasabah dapat lebih tertarik. Program yang kurang efektif adalah penawaran lewat telemarketing dimana nasabah ditelepon oleh funding officer, sehingga nasabah kurang interest karena merasa kurang puas dan merasa kurang memahamiapa yang dijelaskan oleh funding Officertentang produk kartu BRIZZI.

Program marketing public relationsatau funding officerPT Bank Rakyat Indonesia (Persero) Kantor Cabang Yogyakarta dalam meningkatkan jumlah pengguna kartu BRIZZI bisa dikatakan berhasil walaupun masih mengalami fluktuatif.Tetapi funding officer saat ini sudah terbukti dengan tercapainya target pada bulan Oktober.Funding Officer dapat melakukan penjualan jauh melebihi target berkat program-program yang dilakukan oleh marketing public relationsatau funding officer.

\section{KESIMPULAN}

Berdasarkan hasil penelitian yang telah diuraikan, dapat disimpulkan bahwa program marketing public relations yang dilakukan PT Bank Rakyat Indonesia (Persero) Kantor Cabang Yogyakarta dalam menghadapi persaingan yang semakin kompetitif dengan perusahaan perbankan lain yang mengeluarkan produk dengan sistem E-moneyberjalan secara maksimal. Hal ini dapat dilihat apa yang telah dilakukan funding officer dengan program Bundling yaitu penawaran dilakukan secara langsung atau menawarkan produk kartu BRIZZI kepada nasabah yang datang langsung ke Bank BRI. Program ini dapat membuat nasabah lebih tertarik atas penawaran produk BRIZZI oleh funding officer karena komunikasi yang dilakukan secara dua arah sehingga saling memahami dan pelayanan yang menarik.Bundling merupakan program funding officer yang paling obyektif dalam meningkatkan jumlah pengguna kartu BRIZZI. PT. Bank Rakyat Indonesia (Persero) Kantor Cabang Yogyakarta juga melakukan program marketing public relationsmelalui special event, sponsorship, BRIZZI Trans Jogja, directpresentations, telemarketing, exhibitions event, strategi periklanan, bundling, serta BRIZZI co-branding.

Disini dapat dilihat keberhasilan program yang dilaksanakan oleh marketing public relations PT. Bank Rakyat Indonesia (Persero) Kantor Cabang Yogyakarta dalam meningkatkan jumlah nasabah pengguna kartu BRIZZI, walaupun produk ini terbilang masih baru akan tetapi hasil yang dicapai sangat memuaskan, hal ini dapat dilihat dalam grafik pada bulan Oktober. Realisasi yang dicapai jauh melebihi target yang telah ditetapkan, ini merupakan hasil yang terbilang sangat memuaskan dan membanggakan. Semua karna program-program yang telahdilakukan oleh marketing public relationsataufunding officeryang terbilang sukses. Kesuksesan dalam melakukan kegiatan peningkatan jumlah nasabah, ini terbukti tercapainya tingkat pengetahuan dan pemahaman pada nasabah serta target yang diraih dalam meningkatkan pengguna kartu BRIZZI.

Teori pemrosesan dan penerimaan pesan dari Littlejhon dalam bukunya theories of human communication dapat diterapkan dalam penelitian Strategi Marketing Public Relations PT. Bank 
Rakyat Indonesia (Persero) Tbk dalam meningkatkan pengguna kartu BRIZZI. Teori proses pemrosesan dan penerimaan pesan adalah teori yang berorientasi kognitif. Teori ini yang membicarakan persoalan menyangkut hubungan antar stimulus dan respon.Kognitif sendiri mangacu pada pikiran atau benak seseorang, sehingga Kognitivisme memfokuskan bagaimana individu berfikir apabila ada Stimulus dan Respon.Teori pemrosesan pesan dan penerimaan pesan adalah teori yang menitik beratkan pada bagaimana manusia memahami dan mengorganisasikan serta menggunakan informasi yang mengandung di dalam pesan.Teori ini dapat dikaitkan dengan bagaimana merketing public relations dapat mempromosikan suatu produk.

Kaitan penelitian ini dengan teori pemrosesan dan penerimaan pesan dalam kegiatan marketing public relations atau funding officer sebagai bagian aktifitas promosi dalam proses pemyampaian pesan dari perusahaan yang diwakili. Dalam hal ini adalah PT Bank Rakyat Indonesia (Persero) Kantor Cabang Yogyakarta dalam meningkatkan jumlah pengguna kartu BRIZZI agar pesan yang disampaikan dapat diterima dengan baik oleh para nasabah. Hal ini diwujudkan dengan mengadakan berbagai kegiatan promosi seperti membuat kampanye promosi kartu BRIZZI dengan membuat Special Event, Sponsorship, BRIZZI Trans Jogja,Direct presentations (presentasi langsung), Telemarketing, Exhibitions event (Pameran), Strategi Periklanan, Bundling, BRIZZI Co-branding. Kualitas dari produk yang dikeluarkan oleh bank BRI dalam kegiatan program marketing public relations dapat berjalan dengan baik.Semua itu dapat mempengaruhi nasabah dalam berfikir dan melakukan tindakan untuk tertarik menggunakan produk kartu BRIZZI.Maka bisa disimpulkan bahwa kaitan dengan teori yang digunakan telah sesuai dengan penelitian.

Kegiatan marketing public relations atau funding officer sebagai bagian aktifitas dalam proses penyampaian pesan. Perusahaan yang diwakili dalam hal ini adalah PT Bank Rakyat Indonesia (Persero) Kantor Cabang Yogyakarta dalam meningkatkan jumlah pengguna kartu BRIZZI. Pesan yang disampaikan dapat diterima dengan baik oleh para nasabah dan calon nasabah, ini diwujudkan dengan mengadakan berbagai kegiatan promosi seperti membuat kampanye promosi kartu BRIZZI dengan membuat special event, sponsorship, BRIZZI Trans Jogja, directpresentations, telemarketing, exhibitions event, strategi periklanan, bundling, serta BRIZZI co-branding mengenai kartu BRIZZI yang menawarkan tentang berbagai keunggulan yang dapat diperoleh nasabah.

\section{DAFTAR PUSTAKA}

Cutlip, Center, Broom, 2000, Effektive public relations, edisi ke delapan, Prentice Hall, New Jersey.

Gaffar, Vanessa, 2007, Crm dan Mpr Hotel (Costomer Relationship Management Dan Marketing Public Relations) Alfabeta, Bandung.

Jefkins, frank, 1992, Public Relations, pitman publishing.

Krisyanto, Rachmat, 2006, Riset Komunikasi, kencana, Jakarta.

Littlejohn, 1996, Theories Of Human Communication, wadsworth, New York.

Moleong, lexy j, 1991, Metode Penelitian Kualitatif, PT Remaja Rosda Karya, Bandung.

Morissan, 2008, Manajemen public relations: Strategi menjadi humas profesional, kencana, Jakarta.

Ruslan, Rosady, 2002, Manajemen Humas Dan Komunikasi, Konsepsi dan Aplikasi, Raja Grafindo Persada, Jakarta.

Sholikhah, Farida Siti (2016), Strategi Media Relations PT Telekomunikasi Indonesia, tbk untuk meningkatkan citra perusahaan, Jurnal Komunikator, Volume 8. No. 2 : 93-111

Valasco, Edgardo t, dan Abiding, Miranty, 1994, Marketing Public Relations, Upaya Memenangkan Persaingan Melalui Pemasaran Yang Komunikatif, PT Ikrar Mandiri, Jakarta. 